\title{
Yapılı Çevrede Renk Tercihleri
}

\author{
Emine KÖSEOĞLU ${ }^{1 *}$, Elif ÇELIKKAYALAR ${ }^{2}$ \\ ${ }^{1}$ Fatih Sultan Mehmet Vakıf Üniversitesi, Mimarlık ve Tasarım Fakültesi, Mimarlık Bölümü, istanbul. \\ ${ }^{2}$ Yıldız Teknik Üniversitesi, Fen Bilimleri Enstitüsü Mimarlık Anabilim Dalı, Bina Araştırma ve Planlama \\ Lisansüstü Programı, istanbul. \\ *e-mail: koseogluemine@gmail.com

\section{Öz} \\ Renkler, insan yaşamının her anında düzenleyici, ayırt edici ve fark edici unsurlar olarak kullanılmaktadır. \\ Farkında olmadan, algı sınırları içinde düşünülmekte ve tanımlanmaktadır. Simgesel anlamları ile ortak bir 'renk \\ dilinin' oluşması gibi, renkler bir araç olarak her türlü görsel öğe ve insan psikolojisi üzerinden özne ile etkileşim \\ halindedir. Bu çalışmada yapılı çevre üzerinden renklerin cinsiyet değişkeni ile olan ilişkisi irdelenmektedir. Bu \\ iliş̧iyi ölçmek üzere, 40 katılımcıyla bir anket çalışması gerçekleştirilmiştir. Çalışmanın sonuçları, çevrede \\ görülen yapılar ile renklerin bir ilişkisi olup olmadığını, kişilerin yapıları hangi renklerle bağdaştırdığını ve \\ belirtilen renklerin kişilere çağrıştırdığı kavramları ortaya koymaktadır.
}

Anahtar Kelimeler: Renk, tercih, algı, cinsiyet, çevre

\section{Colour Preferences in the Built Environment}

\begin{abstract}
Colour is used as organisator in human life. The concept of colour also has a perceptual dimension. As a symbolic mean, colour has an interaction with the subject through visual elements and human psychology. In this study, by built environment, the relationship between colour and sexuality variables is examined. A questionnaire is conducted with 40 participants to measure this relationship. The results of the study reveal the relationship between the colours of the buildings and user perception; that which colours are associated with specific buildings; and connotations of the colours indicated.
\end{abstract}

Keywords: Colour, preference, perception, sexuality, built environment, space

\section{Giriş}

Renkler, insan yaşamının önemli birer öğesidir. Aynı zamanda insana hitap eden her türlü görsel öğenin içinde yer alarak fiziksel, duygusal, zihinsel ve ruhsal dünyaya çağrışımlarda bulunan, derinden etkileyen bir güçtür. Farkında olmadan yaşamın her anında renkler, kullanılmakta, görülmekte ve algı sınırları içinde düşünülmekte ve tanımlanmaktadır. Tarihten günümüze simgesel anlamlar kazanmalarıyla ortak bir 'renk dilinin' oluşması gibi günlük hayatta da bu renk dilinin iletileri kullanılmaktadır. Dolayısıyla renklerin düzenleyicilik, ayırt edicilik ve fark edilirlik gibi birçok özelliklerinden yararlanılmaktadır.

Renklerin çok farklı algısal karşılıkları olabilmektedir. Örneğin, birçok ülke yol çizgileri için sarı rengi seçmektedir. Sarı renk dikkat çekicidir, aynı zamanda güneşle bağdaştıııı ır ve güneş birçok kültürde umudu ve zi hinsel parlaklığı temsil eder. Sarı, bilgelik, akıllılık ve dikkatin rengidir. Inssan psikolojisinde ise sinir sisteminin düzenli çalışması, depresyon tedavisinde insanların morallerinin düzeltilmesinde destek olan bir renk olarak kabul edilmektedir. Diğeryandan, yangın çıkışlarının hemen hemen hepsi yeşil renklidir. Çünkü yeşilin sakinleştirici etkisi olduğu düşünülmektedir ve sakin karar verilmesi gereken anlarda bu renkten yararlanılmaktadır. Yeşil, aynı zamanda doğanın ve baharın rengidir. 
Sağlık, tazelenme ve yenilenme ifadeleriyle bağdaştııılır. Birçok firma ise yeşilin güven verme etkisinden yararlanmak için logolarında, bu rengi kullanmaktadır.

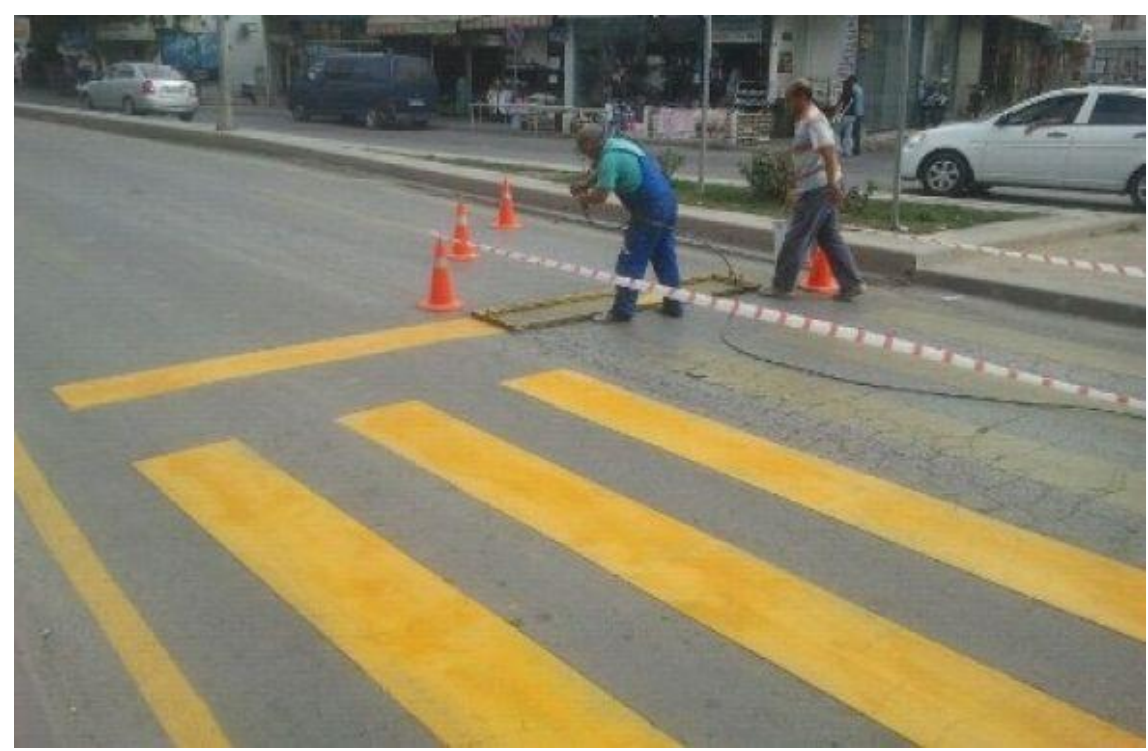

Şekil 1. Kentte rengin kullanımı (URL-1)

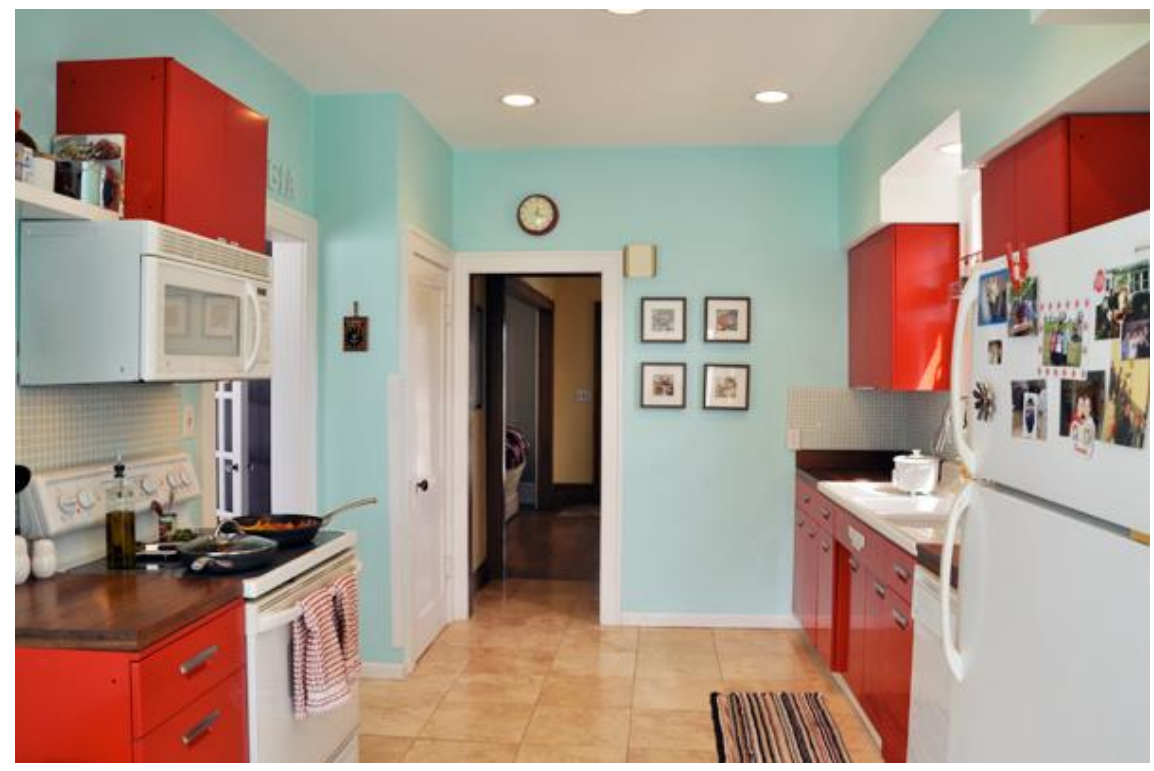

Şekil 2. İç mekanda rengin kullanımı (URL-2)

Uyarı levhaları kırmızı renklidir. En dinamik ve en güçlü renk olan kırmızı, enerji ve heyecan duygularını harekete geçirir. Kan basıncını yükseltir, kalp atışını hızlandırır. Otomotiv sektörü, adrenalin yükseltici etkisi dolayısıyla spor arabalarda bu rengi kullanmaktadır. İnsanlar mavi bir odada, ısıyı kırmızıda olduğundan 4 derece daha az hissederler (Yılmaz, 2008). Gıda sektörüne bakıldığında kırmızının iştah açıcı özelliğinden faydalanılmaktadır. Paketlerin arka planları veya logoları kırmızı ve tonlarında tasarlanmaktadır. Mavi renk ise sükûnet duygusunu iletmektedir (Manav, 2006). Birçok araştırma çocukların duvarları mavi olan okullarda daha uyumlu olduklarını göstermektedir. Batılı ülkelerde ise köprü ayakları maviye boyanarak intihar oranlarının az altılacağı düşünülmektedir.

Birren (1969) renklerin kas sistemi, kasların gerginl iği ve beyin korteksi, kalp atışı, solunum sistemi ve otonom sinir sistemindeki diğer birçok fonksiyon ile ilgili olduğunu saptamıştır. Duygusal ve estetik reaksiyonlar bu şekilde ortaya çıkmaktadır. Bu bağlamda, kırmızı rengin duygusal bir arka planı tetiklediği ve duygusal olarak eyleme geçişle ilgili olduğunu düşünmektedir. Yeşil renk ise kırmızının tersine sakinlik ile ilgilidir. Eyleme geçmeden önce fikirler geliştirilerek gerçekleşmesi için gerekli koşullar hazırlanmaktadır. Yeşil rengin diğer benzer renkler ile birlikte (mavi, turkuaz) konsantrasyonu 
arttıran bir özelliğe sahip olduğu,zihinsel aktivitelerin daha kolay gerçekleştirilmesini sağladığı ortaya konulmuştur. Aydınlığı fazla olan sıcak renkler ise (kırmızı, sarı, pembe vb.) ilgiyi doğrudan rengin olduğu yöne toplayarak eyleme geçmeyi sağlamaktadır. Kas gücüne ihtiyaç duyulan ve bedensel eylemlerin yoğun olduğu yerlerde, fabrika, okul, evlerde bu renklerin kullanılmasının iyi bir düzenleme olacağı düşünülmektedir.

Turuncu, enerji, dışadönüklük, sosyalleşme ve memnuniyet duyularını ifade etmektedir. Kırmızıdan sonraki en sıcak renktir. Bazı araştırmalarda, çocuk mekânlarında canlı ve çarpıcı bir renk olan turuncunun, kırmızı ile birlikte, çocuklar tarafından daha çok tercih edildiği belirlenmiştir. Bunlarla birlikte birçok renk ve renk kombinasyonlarının farklı kullanımlarına dair tercihler mevcuttur. Tek bir renk veya renk kombinasyonları ile harekete geçen duyulara renk duyusu denir (Cheng et al., 2007). Renk duygusu yaş, cinsiyet ve kültürel altyapı ile etkileşim halindedir (Manav, 2006).

Birçok çalışma renklerin duyular ile olan bağıntısını ortaya çıkarmaya yönelik yöntemler izlemektedir. Çocuklarla yapılan bir çalışmada, çocukların neşeli ve mutlu bir hikâye dinledikten sonra sarı boya ile mutsuz bir hikâye dinledikten sonra ise kahverengi boya ile çizim yaptıkları not edilmiştir (Boyatzis ve Varghese, 1994). Genellikle çocuklar her renk için duygusal bir reaksiy on belirtse de renk ile belirgin bir bağıntı kurmaktadırlar (Manav, 2006). Çocuklarla ilgili yapılan bir başka çalışma, 5 ile 14 yaş grubu arasındaki çocukların en favori renk olarak adlandırdıkları ortak rengin kırmızı ve en sevilmeyen rengin ise yaşın artmasıyla birlikte ağırlıklı olarak siyahtan kahverengiye döndüğünü göstermektedir (Friedling, 1974). Farklı meslek gruplarından, 20-50 yaş grubu kadınlar üzerinde yapılan araştırmalarda, çalışan kadınların giysilerinde tercih ettikleri ilk altı rengin, tüm meslek grupları için pembe renk ilk tercih olmakla birlikte, mavi, lacivert, beyaz, kahverengi ve kırmızı olduğunu ortaya konmuştur.

Cheng et al., (2007) tarafından yürütülen bir çalışmada, yaş ve cinsiyet ile renkler arasındaki bağlantı, tüketici ve ürün üzerinden araştırılmıştır. Katılımcılara 120 tekil renk ile 40 renk kombinasyonu sunularak, 5 kategoride katılımcıların renkler ile duyuları nasıl bağdaştırdıkları incelenmiştir. Sonuçlarda, en çok tercih edilen parlak ve pastel renkler, en sevilmeyen ve iç karartıcı durumlarla bağdaştırılan renkler ise koyu renkler olurken kırmızı renk kadınlar tarafından favori, erkekler tarafından ise tercih edilmeyen renk olmuştur. Manav'ın (2006) 50 katılımcı ile yaptığı çalışma ise renkler ve duyuların bağdaştırılması yönünde iki aşamalı bir çalışma olmuştur. Katılımcılara ilk aşamada 30 sıfat verilmiş ve 41 renk ile bağdaştırıl ması beklenmiştir. ilk aşamada verilen cevaplar ile ikinci aşamada, içmekân renklerineilişkin verilen cevaplar arasında ilişki olup olmadığı ve nedenleri gözlemlenmiştir. Sonuçlarda, katıl ımcıların verilen sıfatlar için birden fazla renk önerdiği ve benzer bir şekilde farklı renk örneklerini de aynı sıfatlarla bağdaştırdıkları ortaya çıkmışır. Cinsiyet ve yaş ile siyah renk arasında bir bağlantı bulunmuş, kadınların ve 63 yaş üstü katılımcıların, siyah renge karşı pozitif reaksiyonlar verdikleri ortaya çıkmıştır. Ayrıca, genel olarak, açık ve parlak renkler olumlu cevaplarla bağdaştırılmış, özellikle yeşil rengin hem birinci aşamada, hem de iç mekân araştırmasında olumlu reaksiyonlarla bağdaştırılan ve ev iç mekânlarında tercih edilen bir renk olduğu bulunmuştur. Sema'ya (2006) göre, dış dünyadan algılanan her objektif renk duyumu, iç dünyada sübjektif bir reaksiyona denk gelmektedir. Başka bir deyişle, bu reaksiyonlar özneye göre farklılık gösterebilmektedir. Bu bağlamda, öznenin cinsiyeti, yaşı ve kültürel alt yapısı ile kültürel değişkenleri ve bireysel deneyimleri algı üzerinde etkilidir.

Dalke et al. (2003) kamusal alanlarda yaptıkları çalışmalarda renk kullanımına ilişkin çeşitli sonuçlar elde etmişlerdir. Rengin var olması ya da olmaması o mekanı kullananların farklı tepkiler vermesi ile ilişkilidir. Örneğin, hapishane yapılarında renklerin ve doğal ışı̆̆ın mekanlarda daha fazla kullanılmasının mahkumların iyi yöndeki davranışlarında artışa neden olduğu ortaya çıkmıştır. Daha renksiz, doğal ışıktan mahrum, karanlık hapishane yapılarında ise mahkumların yoksunluk duygusunun artması, monotonluk ve şiddet duygusu ve benzeri negatif davranışları ortaya çıkmıştır. Benzer şekilde hastane yapılarında da renklerin kullanılması ve doğal ışığın düzgün bir şekilde mekanlara ulaştırımasının hastaların iyileşme sürecinde olumlu yönde etkili olduğu ortaya konulmuştur. Bununla birlikte bir hastanede renkler yön bulma, birimlerin ayrılması, acil durumların yönetilebilmesi ve hastanenin işleyişi için önemli rol oynayan faktörler olduğu gibi, kullanıcılar (hastalar, çalışanlarve yönetim) tarafından talep edilen bir uygulama, olması istenen bir durumdur. 
Bu çalışmada yapılı çevreye ilişkin renk tercihleri ve renklerin çağrıştırdığı anlamlar araştırılmıştır. Renkler üzerinden renklerin cinsiyet, yaş ve kültür gibi de ğişkenler ile olan ilişkisi sorgulanmaktadır. Yapılı çevreye ilişkin çağrışımlarve bina türlerine göre renk tercihleri irdelenerek, yapılarla renklerin ne tür bir ilişki içerisinde olduğu ortaya konulacaktır.

\section{Materyal ve Yöntem}

Çalışma, 40 katılımcı ile İstanbul il sınırları içerisinde gerçekleştirilmiştir. Katılımcıların 20'si kadın, 20'si erkek, farklı yaş gruplarından olmak üzere, lisans eğitimi alt sınır olarak belirlenmiş ve katılımcılarından renk tercihlerinin sorgulandığı bir anketi cevaplamaları istenmiştir. Yaş, cinsiyet değişkenleri üzerinde temellenen çalışma, semtlerin ve çeşitli yapı türlerinin renk tercihleriyle ve renklere yüklenen anlamlarla olan ilişkisini araştırmaktadır.

\section{Bulgular ve Tartışma}

\subsection{Bina Türlerine ilişkin Renk Değerlendirmeleri}

Katılımcılardan çeşitli yapıları renklerle bağdaştırmaları ve ne tür çağrışımlarla bu rengi ve/veya renkleri tercih ettiklerini belirtmesi istenmiştir. Her iki grupta da birçok yapı için aynı renk tercihleri söz konusudur. Katılımcılardan eviçin, evi içve dış mekân olarak ayırmaları beklenmiştir. Beyaz renk erkek katılımcılar tarafından \%90 oranında evin iç mekânında tercih edilen bir renk olmuş ve bu rengin tercih sebebi aydınlık ve ferahlık gibi kavramlarla açıklanmıştır. Evin dışı, erkek katılımcılar tarafından \%35 oranında beyaz renk tercihi ile karşılık bulurken, aynı renk, sadelik ve dinginlik ile bağdaştırımıştır. Erkek katılımcıların \%20'si, sadelik ve dinginlik kavramlarını kahverengi ile bağdaştırmıştır. Kadın katılımcılarda ise krem, bej ve tonları gibi açık renklerin tercihi söz konusudur. Kadınların \%45'i bu renkleri evin içinde, \%20'si evin dış yüzeyinde tercih etmektedir. Akromatik renkler olan, beyaz ve gri, ikinci sırada en çok verilen cevaplar arasında yer al maktadır. Ka dınlar krem ve tonlarını evin iç mekânı için huzur, sadelik ve ferahlık ile bağdaştırmış, evin dışı için belirttikleri krem ve tonlarını, beyaz ve griyi sadelik ve dikkat çekmemesi açısından tercih ettiklerini belirtmişlerdir.

Çizelge 1. Kadın katılımcıların 'ev'in içi ve dışı için verdikleri cevaplar

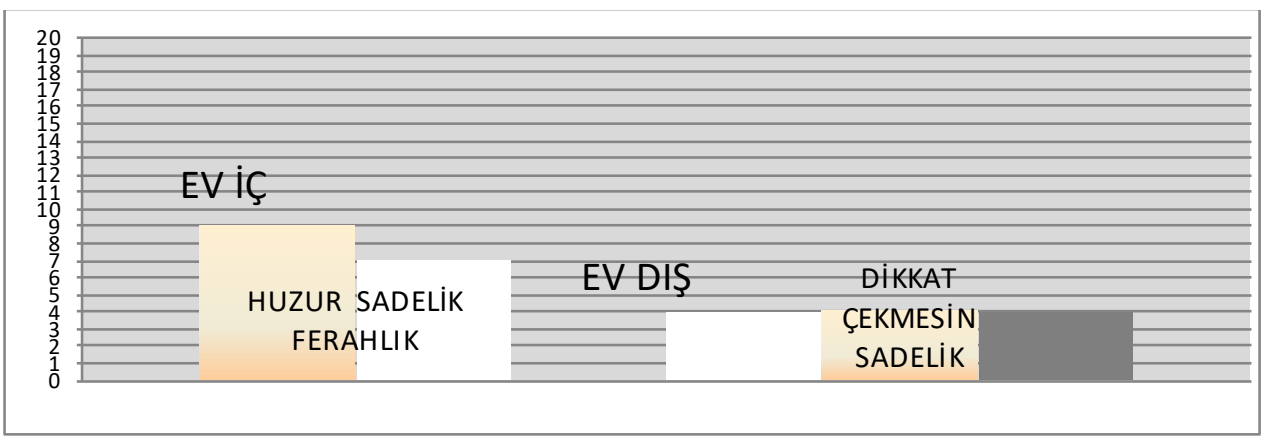

Çizelge 2. Erkek katılımcıların 'ev'in içi ve dışı için verdikleri cevaplar

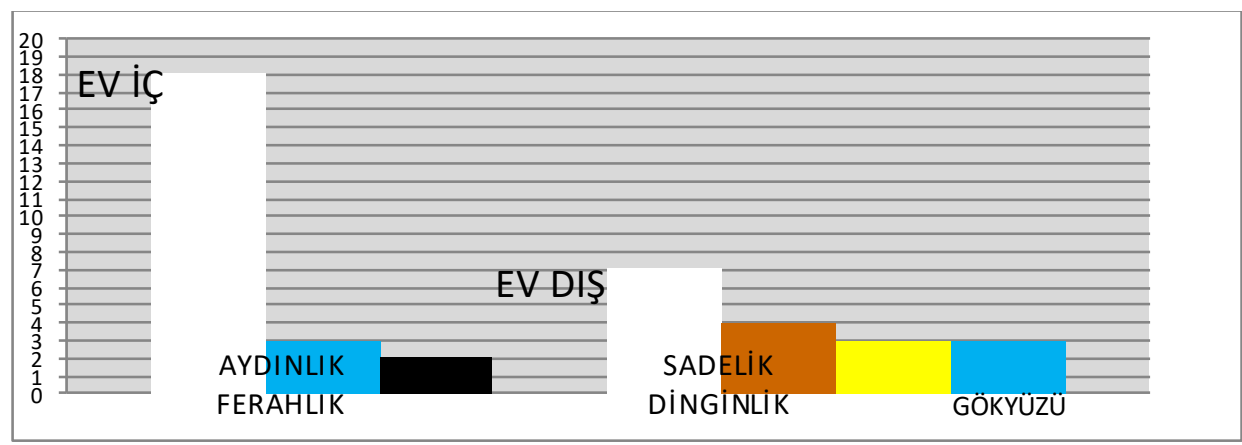

Okul için verilen cevaplarda, her iki grupta sarı renk okulu çağrıştırmış; erkek katılımcılar sarı rengi, neşe ve kalabalık ile kadın katılımcılar ise daha önce okudukları okulların renkleriyle bağdaştırmışlardır. Erkek katılımcıların \%30'u sarı rengi tercih etmiş, bunu bordo renk \%20 oranında takip etmiştir. Bordo rengi, ciddiyet ve kural larla bağdaştırmışlardır. Bunu takip eden kırmızı renk için 
okulların amblemleri ve öğretmen öğrenci ilişkisi, beyaz renk için öğrenme, mavi renk için arkadaşlık gibi kavramlar kullanılmıştır. Daha önce okudukları okulların renkleri, kadınların \%30'unun sarı rengi, \%25'inin kahverengiyi tercih etmesine sebep olmaktadır. Kadın katılımcıların verdikleri cevaplar arasında mavi renk ise disiplin ve üniformaları çağrıştırmıştır.

Çizelge 3. Kadın katılımcıların okul için verdikleri cevaplar

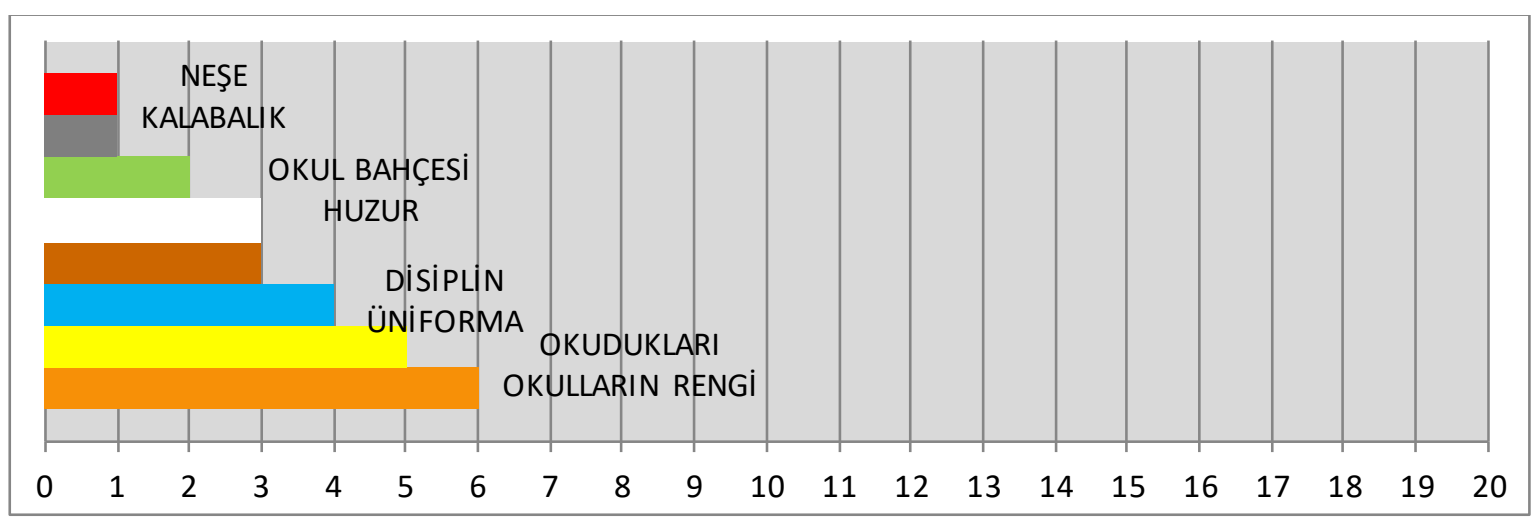

Çizelge 4. Erkek katılımcıların okul için verdikleri cevaplar

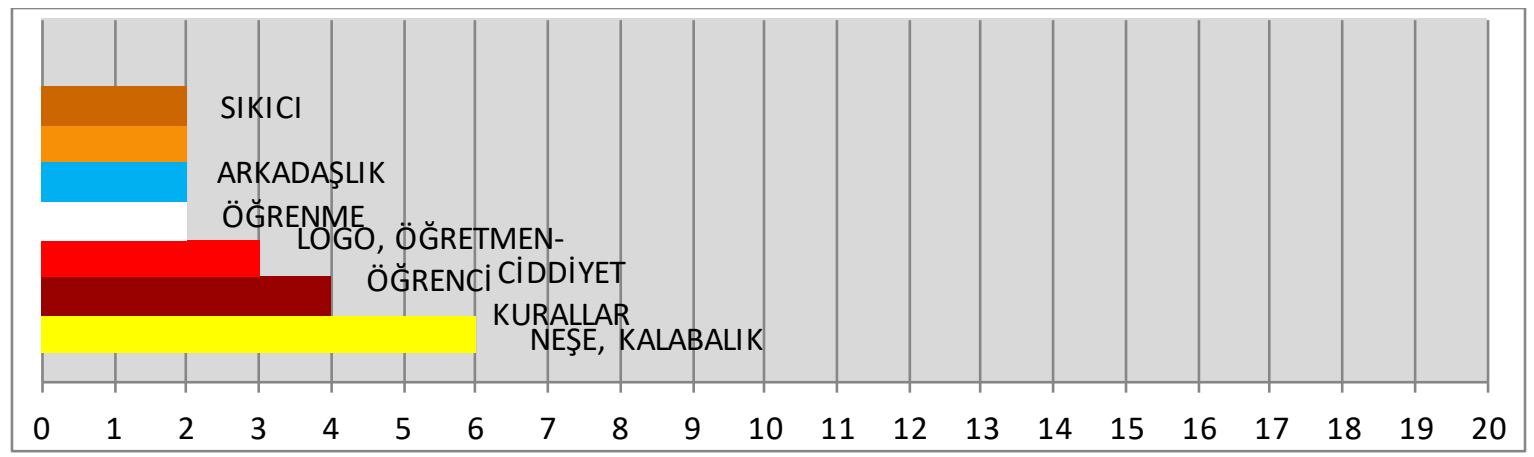

Kütüphane için verilen cevaplarda her iki grubun da kahverengiyi tercih ettikleri görülmektedir. Cevapların çoğu yapının içine yöneliktir. Tüm katılımcıların \%58'i kahverengiyi tercih ederek, bu rengi kitaplar ve mobilyalar ile bağdaştırmışlardır. Erkek katılımcılar kadın katılımcılara göre daha az renk seçenekleri sunarak ağılıklı olarak kahverengi ve sarı renkleri tercih etmişl erdir. Erkek katılımcılar da bu renkleri içe yönelik, kâğıt - kitap gibi nesnelerle bağdaştırmışlardır. Kadınlar kahverengiden sonra farklı renklerde birçok kitabın bir arada bulunması nedeniyle rengârenk cevabını vermişlerdir.

Çizelge 5. Kadın katılımcıların kütüphane için verdikleri cevaplar

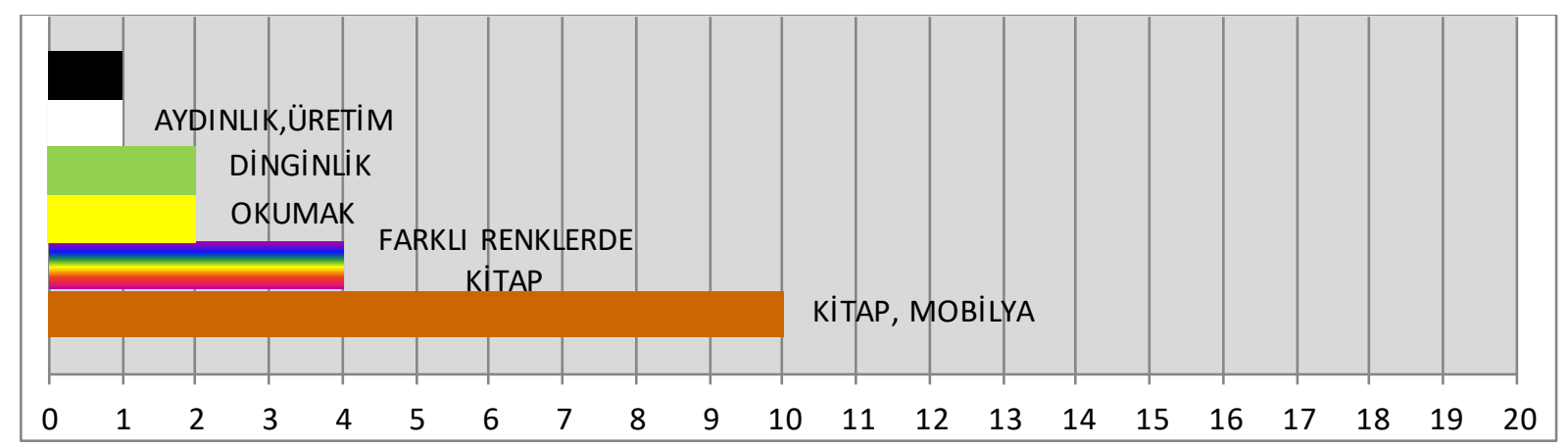


Çizelge 6. Erkek katılımcıların kütüphane için verdikleri cevaplar

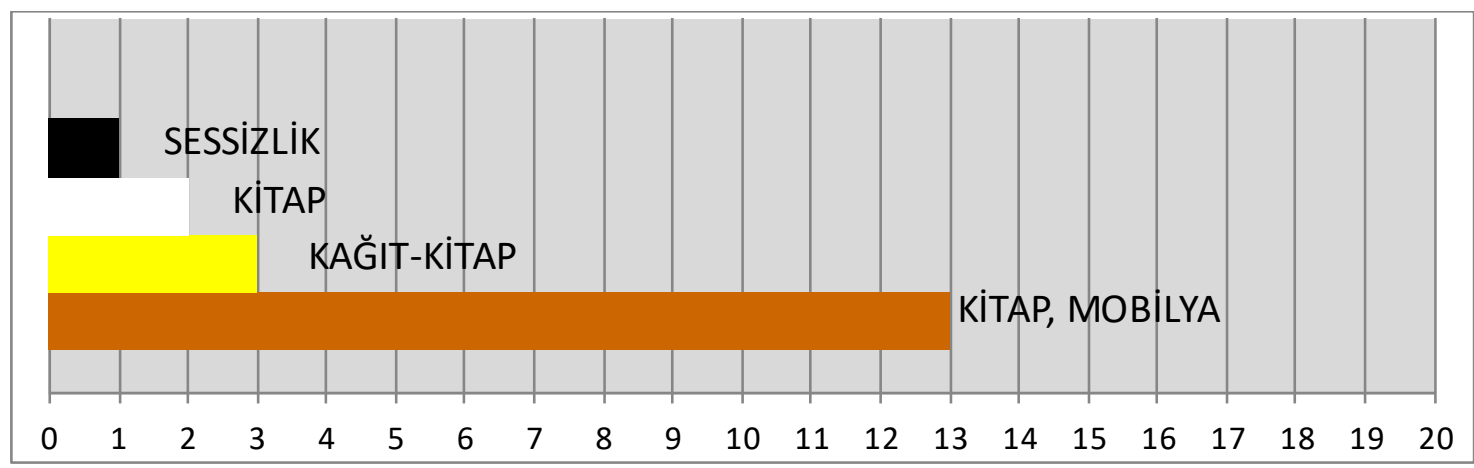

Beyaz, hastane rengi olarak katılımcılar tarafından en çok tercih edilen renk olmuştur. Kadınlarda bu oran $\% 70$, erkeklerde $\% 80$ 'dir. Hastanenin beyaz ile bağdaştırılmasında temizlik ve hijyen gibi kavramlar etkili olmuştur. Kadınların \% 20 si gri rengi hastalık ve kasvet ile erkeklerin \%10’u sarı rengi hastalık ve ayrılık ile bağdaştırmaktadır. Hastane yapısı için kadınların erkeklere göre daha fazla renk seçeneği sundukları saptanmıştır.

Çizelge 7. Kadın katılımcıların hastane için verdikleri cevaplar

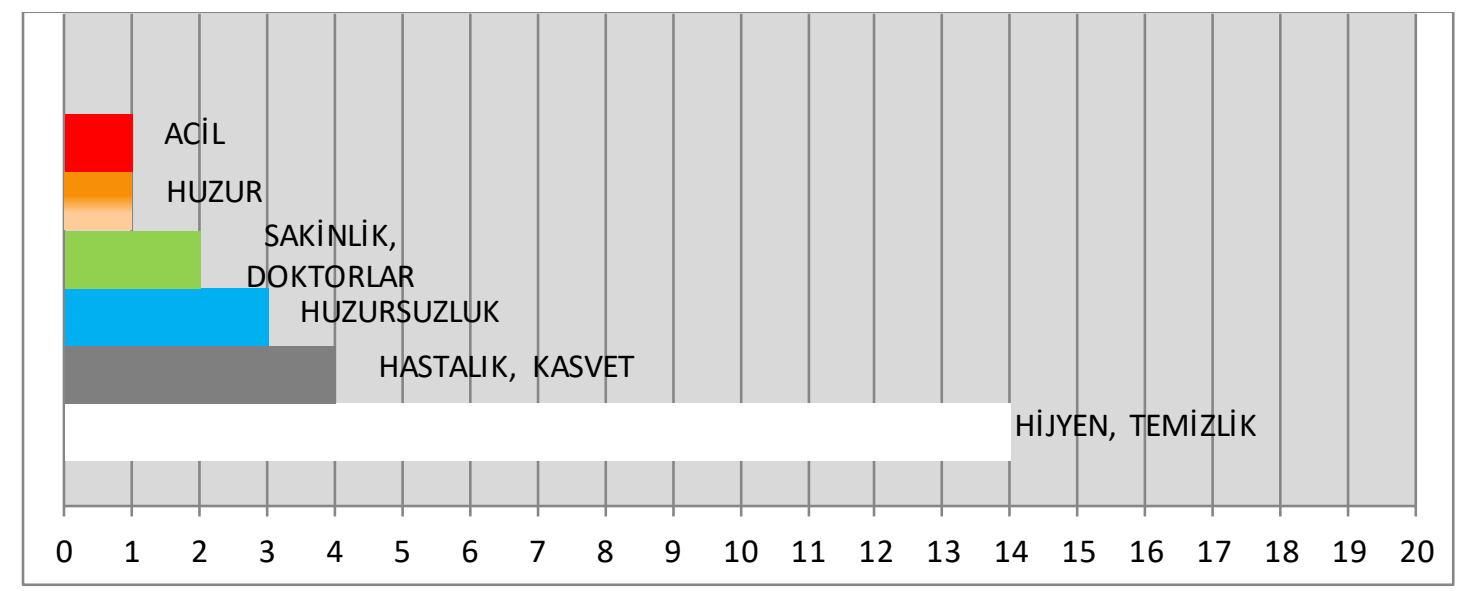

Çizelge 8. Erkek katılımcıların hastane için verdikleri cevaplar

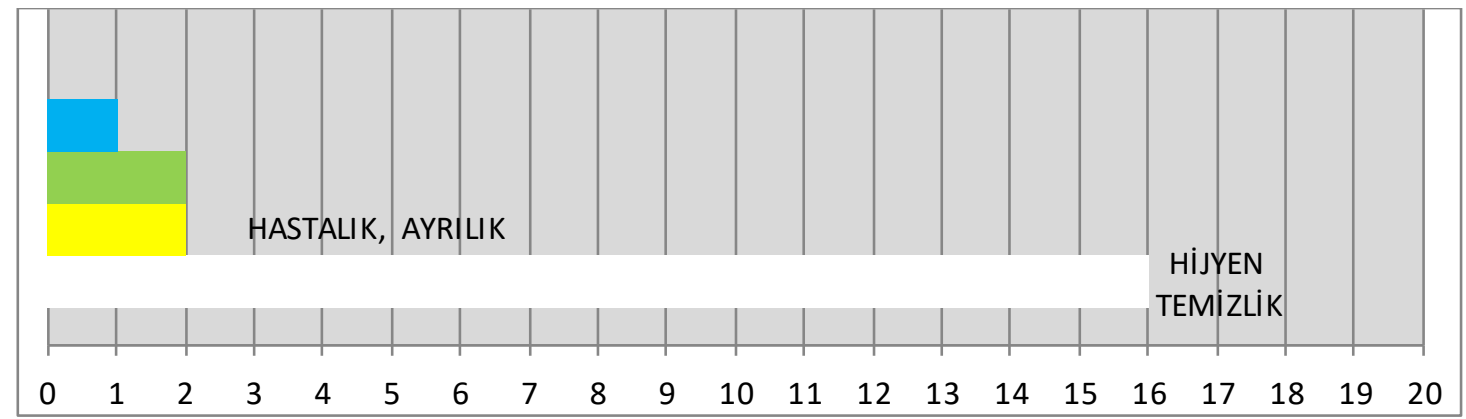

Otel yapısı, mavi ve yeşil renklerin çoğunlukta olduğu tercihlerden oluşmaktadır. Renkler, deniz, tatil ve doğa kavramları ile bağdaştırımaktadır. Erkek katılımcıların verdikleri cevaplarda, mavi renk tek başına \%30 oranında deniz ile bağdaştırıl mıştır. Mavi - yeşil kombinasyonu, \%15 oranında deniz, tatil ve doğa ile bağdaştırımaktadır. Erkek katılımcılar, kırmızı rengi tek başına eğlence olarak yorumlamıştır. Kadın katılımcıların \%20'si mavi ve yeşili birlikte tercih etmişlerdir. Mavi ile beyaz aynı oranda bunu takip eden renkikilisi olmuştur. Kadınlar beyaz rengi sadelik ve sakinlik, beyaz - kırmızı kombinasyonunda, kırmızı rengi eğlence, beyaz rengi dinlenme olmak üzere tercih etmişlerdir. Kadınların verdikleri cevaplarda gri renk oda rengi olarak belirtilmiştir. Sarı ve mavi renkler tekil olarak tercih edilmiştir. Sarı renk güneş ile mavi renk ise sakinlik ile eşleşecek şekilde cevaplanmıştır. 
Çizelge 9. Kadın katılımcıların otel için verdikleri cevaplar

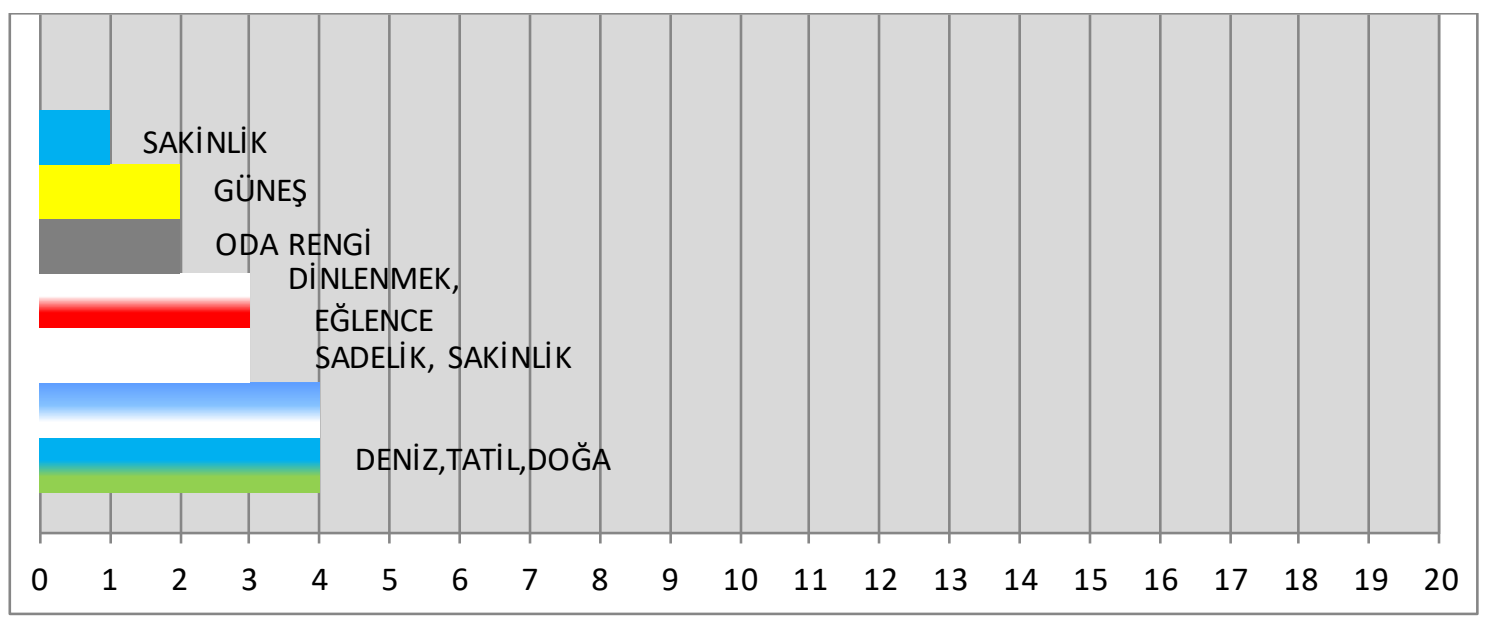

Çizelge 10. Erkek katılımcıların otel için verdikleri cevaplar

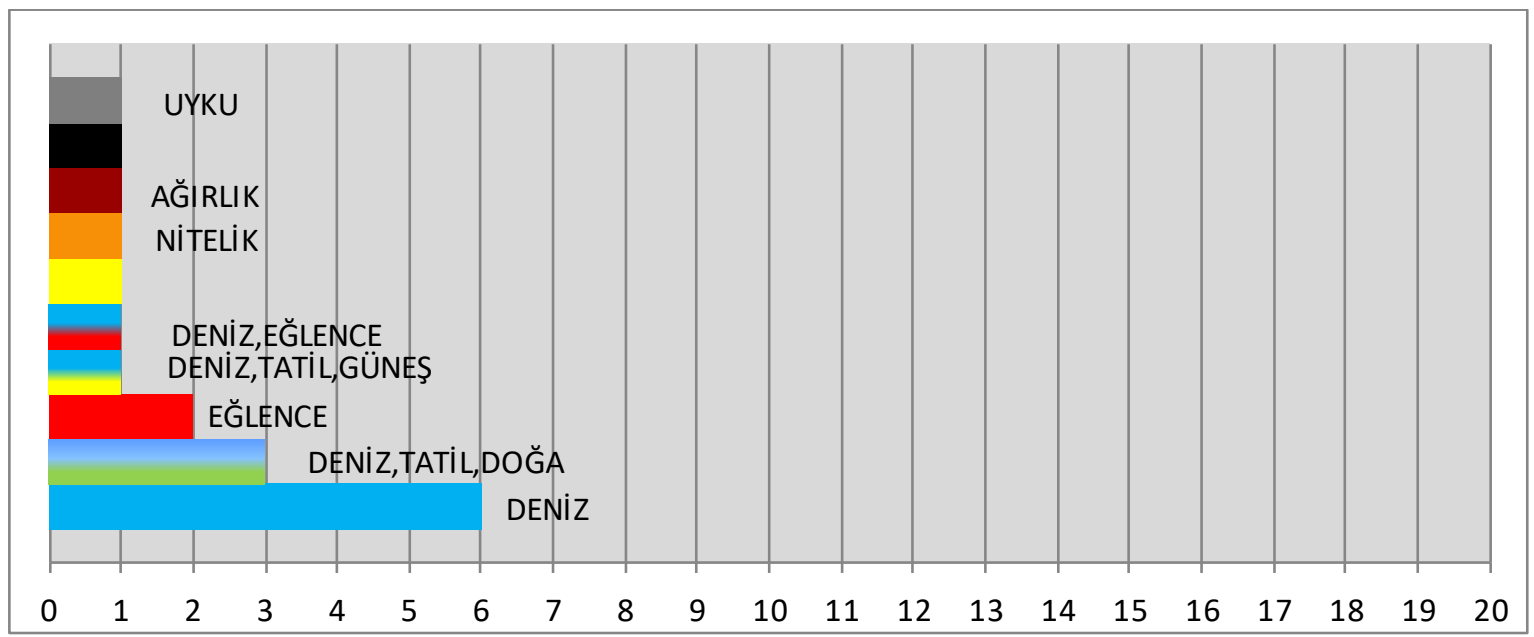

Restoran için iştah açıcı renkler olarak adlandırılan renkler tercih edilmiştir. Her iki grupta da en çok verilen cevap, toplamda \%53 oranında kırmızı olmuştur. Kırmızı iştah açıcı olması açısından her iki grupta da aynı cevaba denk gelmektedir. Aynı zamanda bu renk kadınlar için hareketlilik olarak da yorumlanmıştır. Erkek katılımcılar kırmızıyı iştah açan bir renk olarak algılamalarının yanında restoran logolarının da bu rengi seçmelerinde çağrısım yaptırdığını belirtmişlerdir. Kırmızı rengi turuncu ve yeşil renk izlemektedir. Kadınların \%25'i turuncu rengi enerjik ve iştah açıcı bir renk olarak adlandırmış, $\% 25^{\prime}$ i yeşil rengi, yemek yemenin rengi olarak görmüştür. Erkeklerde bu oran yine $\% 25^{\prime}$ erlik bir dağılımla turuncu ve yeşil arasında aynı kavramlara denk gelmektedir. Erkek katılımcılar turuncu için ayrıca doğalıı kavramını da eklemişlerdir. Kadın katılımcılar beyaz rengi hijyen olarak adlandırmış, erkek katıımcılar bu rengi temizlik ile bağdaştırmıştır. Sarı renk ise kadınlarda yemek yapma ve pişirmeye, erkeklerde ise hijyene denk gelmektedir.

Çizelge 11. Kadın katılımcıların restoran için verdikleri cevaplar

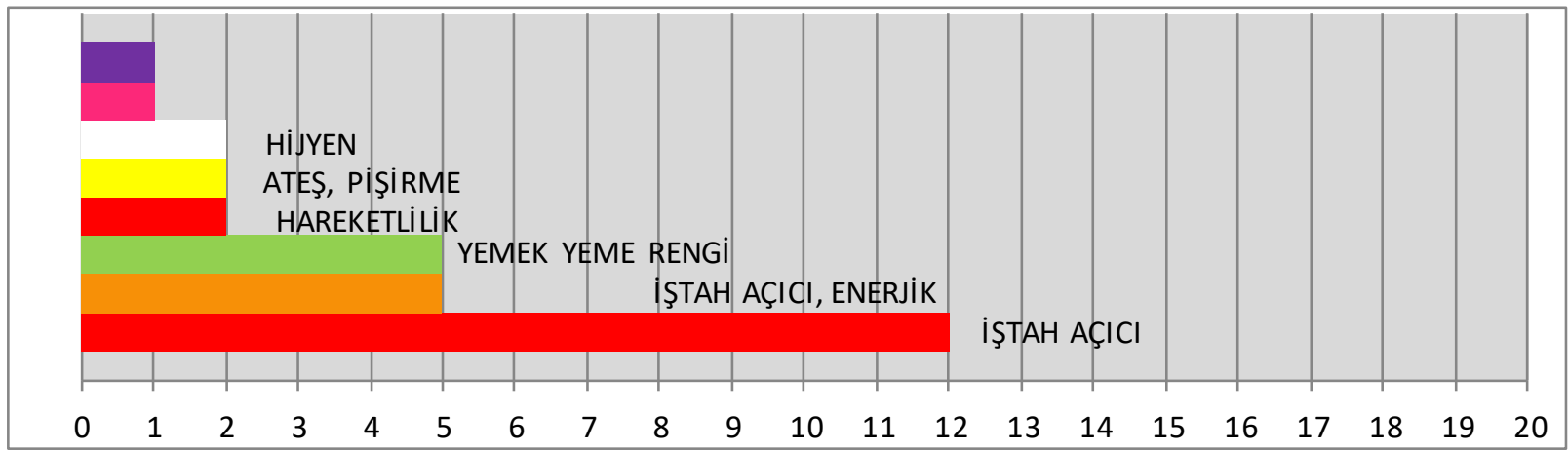


Çizelge 12. Erkek katılımcıların restoran için verdikleri cevaplar

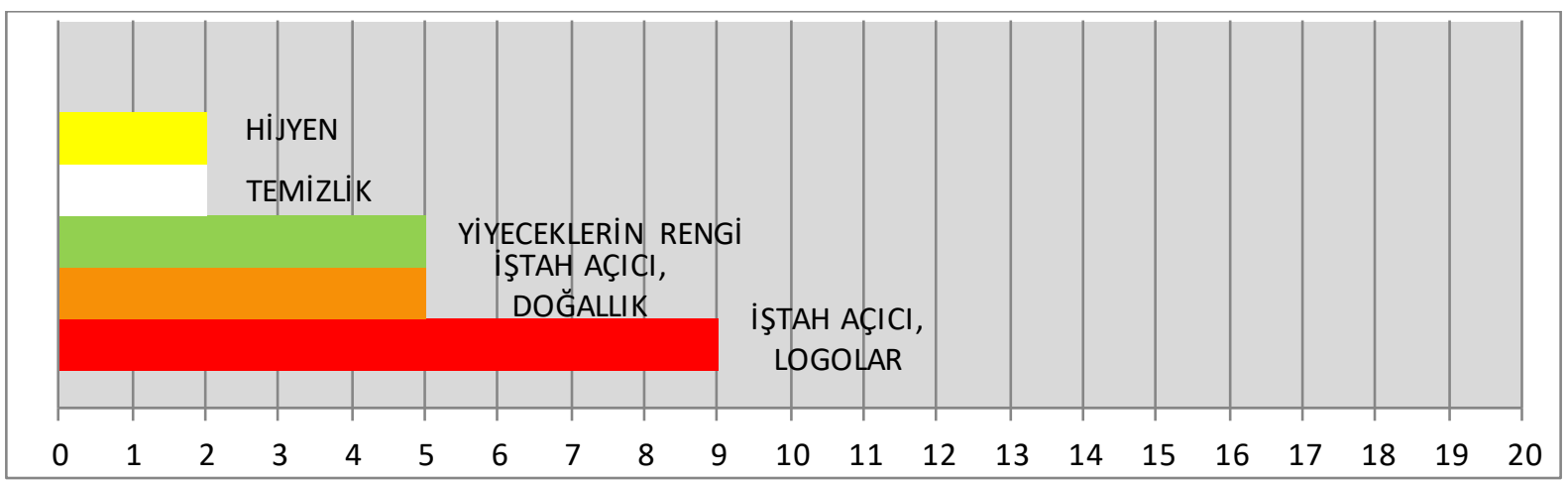

\section{Sonuç ve Değerlendirme}

Bu çalışmada, yapılı çevreye ilişkin renk tercihleri, tercih edilen renklerin kullanıcılar için ne anlam ifade ettiği ve renk tercihlerinde cinsiyete göre farklılıklar olup olmadığı araştırılmıştır. Yapılan eşleştirmelerde, bir renk birden fazla kavrama denk gelirken, bir kavram da farklı renklerle bağdaştırılabilmektedir. Aynı zamanda, renklerin yapılar için ne gibi çağrışımlar yaptığıyla ilgili katılımcıların ağılıklı olarak yapıların bütününden ziyade içmekânı tanımlayan obje ve renkl eri o yapı ile bağdaştırdıkları görülmektedir. Katılımcılar çevrelerinde gördükleri binaların renklerinden memnun olmadıklarını belirtmişlerdir. Mevcut renkleryerine beyaz renk tercihi ön plana çıkmaktadır. Cinsiyetin de renk algısında önemli bir faktör olduğu ve kadınlar ile erkeklerin kişisel renk tercihlerinde farklılıklar görüldüğü saptanmıştır. Örneğin, okul için verilen cevaplarda kadın katılımcıların tercihlerinde okudukları okulların renkleri etkili olurken, erkek katılımcıların tercihlerinde neşe ve kalabalık gibi kavramlar etkili olmuştur. Öte yandan, yapılı çevrenin renklerle bağdaştırılması konusunda büyük farklııklar gözlemlenememektedir. Kütüphane ve/veya hastane yapıları için verilen cevaplarda benzerlikler fark edilmektedir. Kütüphane kahve rengi ile iç mekana yönelik algılarla, hastane ise beyaz renk ile hijyen gibi kavramlarla bağdaştırı mıştır.

Mimariden, modaya, mobilyadan ürün paketlerine ve düzenleyici kurallara kadar renkler insan yaşamında önemli bir yer tutmaktadır. Farklı işlevlere sahip mekânlardaki farklı renk düzenleri, o mekânlardaki görsel estetik kalitesini arttırırken, işlevsel özellikleriyle de mekânları daha yaşanılır ve uyumlu kılmaktadır. (Tuncay 2006) Renkler, psikolojik etkiler oluşturarak, farklı boyutlarda ve mekânsal anlamda farklı ölçeklerde özne ile görsel bir iletişime geçmektedir. Bu bağlamda, iç mekânlarda, yapılarda ve kentlerde kullanılan renkler bir ruh hali yaratmaktadır.

\section{Kaynaklar}

Birren, F. (1969). 'The Psychology of Color and Illumination', Psychological Implications of Color and Illumination, Color Consultant, Newyork, Mayıs 1969.

Cheng, H., Lee, K., ve, Lee, H., (2007). 'Color Preferences of the Korean Elderly', International Association of Societies of Design Research, The Hongkong Polytechnic University, 12-15 Kasım 2007.

Dalke, H., Camgöz, N., Bright, K., Cook, G., Littlefair, P. ve Loe, D. (2003). 'Research with Users: Colour Design and Lighting for Public Transport, Prison and Healt Care Environments', The Colour, Light and Contrast Manual: Designing and Managing Inclusive Built Environments, Wiley - Blackwill Publications, Mart 2010.

Friedling, H, (1974). 'Farbe in Raum', Callwey Verlag, Münih.

Manav, B. (2006). 'Color-Emotion Associations and Color Preferences: A case Study for Residences', Color Research and Application, Wiley Interscience Publications, Vol.32, No.2.

O'Connor, Z. (2008). 'Facade Colour and Aesthetic Response: Examining Patterns of Response Within the Context of Urban Design and Planning Policy in Sydney', The University of Sydney, Faculty of Architecture, Design \& Planning, Doktora Tezi.

Tuncay, S. (2006). 'Mimarlık ve Renk Kavramı', İstanbul Üniversitesi, Sosyal Bilimler Enstitüsü Psikoloji Anabilim Dalı, Y.Lisans Tezi., İstanbul. 
Yılmaz, A. (2008). 'Mimarlık ve Renk Tasarımı Eğitim Notları', TMMOB Mimarlar Odası, Sürekli Mesleki Gelişim Merkezi, İstanbul.

URL-1. http://www.tumhaber.com.tr/HaberOku.php?haber_id=101928

URL-2 http://www.ikeamobilya.net/tag/kirmizi-mutfak-dekorasyonlari/ 